\title{
ATTITUDES OF INDIGENOUS ACEHNESE PEOPLE TOWARDS THEIR VERNACULAR MAINTENANCE IN LANGSA.
}

\section{Fakhrurrazi}

State University of Jakarta

fak.brurrazi.amin@gmail.com

\begin{abstract}
This research is a study on native people's attitudes towards Acehnese language in Langsa Aceh. The research design used a qualitative research method that examines the attitudes of native speakers of the language of Aceh in Langsa in prewserving the language. The subject of research is the native speakers of Acehnese who live in the city of Langsa from eighteen years to twenty years old. This study used observation, questionnaire and interview. The data obtained from this study were analyzed based on the cooperative model intrcidued by Miles and Hubermann. The study shows that $55 \%$ of respondents indicates a very positive attitude towards in preserving the Acehnese by using the language in everyday communication. While $45 \%$ of respondents indicates a negative attitude where they seldom use Acehnese in their daily interaction and very often switch the language to Indonesian in their communication. The study also reveals that the use of Acehnese at home, the pride of using Acehnese and the Acehnese as identity are the factors that contribute to the preservation of Acehnese.
\end{abstract}

\section{Keywords}

Language attitude, language maintenance, vernacular and language shift.

\section{INTRODUCTION}

Globalization and high community mobilization affect Acehnese social life, almost all aspect of Acehnese influenced by globalization which is hard to control. It is not only leads the Acehnese community to a better life, such as the development of information and technology that will be able to ease relation in society, but it also supports negative effect to Acehnese especially for Acehnese who live in Langsa, they become egoistic, apathetic, and show their life style which are not suitable to Acehnese norm. The influence of globalization affects action, awareness, and attitudes some of Acehnese 
community to the use of their vernacular. This can be seen in the phenomena of less frequent of using Acehnese vernacular, where they tend to speak Indonesian rather than their own vernacular in daily interaction in working place, family, and public places. For instance, when the leader of community announces something, or even in an important community meeting they use Indonesian language.

Furthermore there are many youths of Acehnese who cannot speak or understand Acehnese vernacular, this indication is very risky for the existence of Acehnese vernacular, Especially the young generation at the age of 18 to 20 years old on the street, market, office and some other places tend to speak other language such as Indonesia rather than using their own vernacular, this can be seen when someone asking something in Acehnese he/she tend to response by using Indonesian language. Sneddon (2003) says that the pressure of Indonesian to local languages is very great and leads to their endangerment. It implies that the speakers' loyalty to their vernacular is in challenge. Moreover, Musgrave (2009) states that using the national language could be viewed as a mark of good citizenship. It implies that there is a high pressure to the use of Acehnese vernacular.

To this, there are two indications of Acehnese vernacular usage can be taken into consideration; when they have high loyalty, it means they maintain their vernacular. But when their attitude shows negative or less respectful to their vernacular, it means their language may be altered by another one. Moreover, there is a lack of eagerness from the children at school age to use Acehnese vernacular in their interaction, it is proven by Iskandar (2008) research on the students' attitude on using Acehnese in family, community and school. It is shown that $26 \%$ of the students in Banda Aceh disagree to use Acehnese vernacular because it will constrain their knowledge, difficult to 
reach the development and to use Acehnese will only limit their perception on regionalism which lead to disintegration, Acehnese vernacular is considered less communicative and it is only understood by a certain ethnic. It is implied that they have less positive attitude to Acehnese vernacular, whereas attitudes are crucial in language growth or decay (Batang, 2010). Consequently, to make sure the language or vernacular is maintained, it is needed to have positive attitude from its own speakers.

Furthermore, parents seldom guide their children to speak Acehnese vernacular in their family and they feel proud when their children are able to speak Indonesian or foreign language fluently since the beginning. At school, starts from Kindergarten (TK), Elementary school (SD) to University level the students learn foreign language dominantly compare to Acehnese vernacular and Indonesian language. Even, social interaction in public places also gives limited access to the use of Acehnese vernacular by appearing some shopping center to replace traditional market, where it gives no chance to do an interaction in the form of verbal communication, or even there is no social interaction happened between buyer and seller because of using of machine or computer in interaction. By doing so, the use of Acehnese vernacular in Langsa is decreased.

In addition, Langsa is multilingual community since the community in Langsa does not only consist of Acehnese but some other ethnic groups as well. It allows choosing any code or variety in social interactions. These choices may have potential longer-term effects on the languages existing in a community that is Acehnese vernacular. Nowadays, there is an indication that Acehnese vernacular is sidelined from Acehnese community daily life especially from its young generation due to young speaker is easy to adopt new things, and Acehnese vernacular is signaled unable to fulfill the need of 
its speaker for the life in a nation, particularly for the need of economic aspect.

The above description is about behavior of Acehnese community especially young generation to their vernacular where it is assumed that attitude is one of the factors contributes to do so. Though Acehnese vernacular is an important identity to determine a certain ethnic group, seems it is not always can be maintained, but it does not meant that Acehnese vernacular must be left behind. Acehnese vernacular precisely need to be made useful in order not to be shifted or lost.

From the research that will be conducted, it is hoped that will be able to contribute some ideas to elaborate the attitude of the indigenous Acehnese people towards their vernacular maintenance, to describe attitude realization of indigenous Acehnese people towards their vernacular maintenance. And to find the reasons for their attitude among speakers of the indigenous Acehnese people.

\section{Attitudes}

The word attitudes is mental phenomenon, as Baker (1992) states that attitudes is considered as mentality phenomenon which cannot be examined and observed directly but it is manifested in the form of action. It refers to a hypothetical construct used to explain the direction and persistence of human behavior. So it can represent internal thoughts, feelings and tendencies in behavior across a variety of contexts.

In accordance to attitudes, Fishman (1970) states that there are mentalist and behaviorist viewpoint. Based on the mentalist view, attitudes are a mental and neutral state of readiness which cannot be observed directly, but must be inferred from the subject's introspection. According to 
behaviorism, attitudes are a dependent variable that can be statistically determined by observing actual behavior in social situations.

Moreover according to Lambert (1982), attitudes consist of three components: the cognitive, affective and conative components. Then, Batang (2010) explains that the cognitive component refers to an individual's belief structure, the affective to emotional reactions and the conative component comprehends the tendency to behave in a certain way towards the object.

In accordance to the above explanation, Bagozzi (1992) also provide explanation in more detail that cognitive refers to the process of coming to know and understand; or in other words it is the process of encoding, storing, processing, and retrieving information. It is generally associated with the question of "what" (e.g., what happened, what is going on now, what is the meaning of that information). Affective refers to the emotional interpretation of perceptions, information, or knowledge. It is generally associated with one's attachment (positive or negative) to people, objects, ideas, etc. And it is associated with the question "How" (e.g., how do I feel about this knowledge or information), while conative refers to the connection of knowledge and affect to behavior and it is associated with the issue of "why". So, it is the personal, intentional, planful, deliberate, goaloriented, or striving component of motivation, the proactive (as opposed to reactive or habitual) aspect of behavior. Therefore, it is closely associated with the concept of volition, defined as the use of will, or the freedom to make choices about what to do.

Through these three components people try to know the attitude of someone towards the object. It means that it has an evaluative aspect, which is a disposition and tendency to react to something. 


\section{Attitudes towards Language}

As attitudes are mental phenomena which cannot be observed directly but it is normally manifested in the form of action. Therefore, condition and process to form language attitudes is not quite different from the attitudes in general, accordingly language attitudes is mental phenomena and must be observed through the behavior or the use of language by language users. So, it can be assumed that language attitudes can be defined as positive or negative evaluation of language. As stated by Yusri (2011) attitude towards a language refers to the perception of a community towards that language. Therefore it has a tendency to react in a certain way either positive or negative.

\subsubsection{Positive Language Attitude}

Language positive attitude is to use or to treat the language positively in daily interaction. In line with this, Garvin and Mathiot (1968) formulate the following category of positive language attitude:

- Language Loyalty, where the people of a certain language encourage themselves to maintain their own language and prohibit the effect of other language if it is needed.

- Language Pride, where the people of a certain language encourage themselves to spread and use the language as a symbol of identity and symbol of unity.

- Awareness of the Norm, where the people of a certain language encourage themselves to use the language politely and accurately. This is considered as a dominant factor to influences the action of language use.

Those three categories are categories for positive language attitudes. A positive language attitude is an eagerness of the community to use the 
language in all domains. It is believed that the positive language attitude categories above support the language to be maintained even though language is always come in contact. In accordance to positive attitude to the language, there are some categories provided as in UNESCO document on endanger language (2003).

\section{Table I}

\section{Attitude of community members towards language}

\begin{tabular}{|l|l|}
\hline Category & \multicolumn{1}{c|}{ Attitudes towards language } \\
\hline \multirow{3}{*}{ Positive } & $-\quad \begin{array}{l}\text { All members value their language and wish to see it } \\
\text { promoted }\end{array}$ \\
- & $\begin{array}{l}\text { Most members support language maintenance } \\
\text { others are indifferent or may even support language } \\
\text { shift. }\end{array}$ \\
\hline
\end{tabular}

(Adapted from Unesco, 2003)

Holmes (2001) states that positive attitudes support efforts to use the language in variety of domains, and this help people resist the pressure from majority group to switch to their language. When community members' attitudes towards their language are very positive, the language may be seen as a key symbol of group identity. It is as people value family traditions, festivals and community events, members of the community may see their language as a cultural core value, vital to their community and ethnic identity (Unesco, 2003).

As we know nowadays English and national language play a prominent role in daily interaction. Therefore, positive attitude is considered as crucial 
element in language growth (Fishman, 1991). It implies that community need to have positive attitude to their own language to make sure their language is maintained.

\section{Negative Language Attitude}

Negative attitude is the decrease of loyalty from members' community to the language they have used. Such attitude will lead the language to shift, loss, or death, as mentioned in a Unesco document (2003), if positive attitude to language does not occur, or weak from someone or from a group of people of a certain language, it means that those people contribute negative attitude to their language. Such negative attitude to the language can lead to the language shift, loss or death.

Negative attitude to language can also be happen when people or a group of people do not feel proud of their own language anymore, it occurs when ethnic language is not highly valued and is not seen as a symbol of identity. This is happen when teenagers or young generation gradually abandon to use ethnic language or vernacular in daily communication, or if members view their language as hindrance to economic mobility and integration into mainstream society, they may develop negative attitudes towards their language (Unesco, 2003). In accordance to negative attitude to the language there are some categories provided by Unesco in document on endangered languages (2003).

\section{Table II}

Negative attitude of community members towards language

\begin{tabular}{|c|c|}
\hline Category & Attitudes towards Language \\
\hline & $-\quad$ Some members support language maintenance; some \\
\hline
\end{tabular}




\begin{tabular}{|c|c|c|}
\hline \multirow{3}{*}{ Negative } & & are indifferent or may even support language shift. \\
\hline & - & $\begin{array}{l}\text { Only a few members support language maintenance; } \\
\text { many are indifferent or support language shift. }\end{array}$ \\
\hline & & $\begin{array}{l}\text { No one cares if the language is given up; all prefer to } \\
\text { use a dominant language. }\end{array}$ \\
\hline
\end{tabular}

(Adopted from Unesco, 2003)

Although the language of a particular group or society can be used as a symbol of identity and unity, this alone may not suffice to assure its maintenance in an environment where conditions exist promoting language shift.

Therefore, when people or communities abandon its original language, the language is in challenge because once the owner of language show negative attitude the process of language shift is happened.

\section{RESEARCH METHOD}

This study was conducted in qualitative research design in order to describe the attitudes towards Acehnese vernacular maintainance occurrence among Acehnese speakers in Langsa. Berg (2007: 3) as quoted by Djam'an qualitative research thus refers to the meaning, concept, definitions, characteristics, metaphors, symbols, and description of things. Qualitative design attempts to describe what is going on and what data shows. Therefore, in order to understand the phenomena, the researcher elaborates the study, make a list and present it descriptively.

The written results contained quotations from data to illustrate and substantiate the presentation. The data include (1) observation, (2) questionnaire, and (3) interview. 
Natasha (2005: 15) says that observation is the way of collecting data which is done through looking, listening and taking note about the indications accur from subject of the research. This research applied direct observation through looking, listening and taking note about phenomenas on the Acehnese vernacular maintenance among Acehnese speaker in Langsa. It means that researcher did observation in the field to look at the phenomena which relate to the efforts and supporting reason to their attitudes towards Acehnese vernacular maintenance through taking note on those phenomena.

Questionnaire was conducted to gain the data or information from the subject of the research about perception, feeling and thinking on Attitude towards Acehnese vernacular maintainance. And interview; According to Bogdan and Biklen (1992: 108) interview is the way to capture a word-picture of setting, people, actions, and conversation. Furthermore, Seidman (2006) says that interview in a research is aiming at collecting information about human life, their point of view in society and it is also as a main support for abservation.

Based on the above explanation, interview is a process asking and answering between researcher and research subject for the purpose of getting information data, opinion, point of view orally from the subject. In this research it was applied structured interview. It means interview was held to the subject by using guideline that will be asked to the subject base on the research purpose and to the problem in maintening Acehnese vernacular. A set of interview transcript could be able to get data and explanation from the subject accurately.

The sources of the data of the study are indigenous Acehnese people who live in Langsa, it was based on the purposive sampling technique. According to Miles (1994) Qualitative samples tend to be purposive, rather 
than random. The key feature of qualitative sampling is researcher usually works with small samples of people, nested in their context and studied indept. Therefore, it was assumed that samples were selected based on the knowledge of population and the purpose of the study.

The researcher focused the area of his research only in Langsa Kota, since Langsa Kota is not only Acehnese as a majority of ethnic group in but it has multi ethnic groups inhabiting in this area as well (Statistic Bureau : 2012). The data consisted of children as the younger generation. Where the age of the children is about 18 to 20 years old due to the younger generations are normally interested in new things and they are easier to be influenced by another language. The data collected from the respondents are based on their family background, neighbor, school and their home.

\section{RESEARCH METHOD}

The data were collected from questionnaire and interviews were analyzed in different techniques. The data of Acehnese attitude to their language which were taken from questionnaire was analyzed by using the following steps: (1) reduction the data into positive and negative attitude they have, (2) data display through textual representations on Acehnese language attitude, (3) verification and drawing conclusion. The conclusion of Acehnese language attitude is drawn base on pattern apparent from the data.

The data from interview of why Acehnese indigenous people show positive or negative attitude and the reasons contribute to positive or negative attitude were analyzed by (a) transcribing the data from tape recorder into written transcription, (b) classifying data into some categories of factors contribute to positive or negative attitude they have, (c) verifying the data through asking interview participant to confirm that what was 
represented in the text is a true reflection of what occurred during the interviews, and (d) concluding the reason of language attitude and reasons to show to positive and negative attitude through applying interactive model which mean it was conducted after all process of data analysis was conducted such as data collection, data reduction and data display.

Figure I

Interactive Model of Drawing Conclusion Process

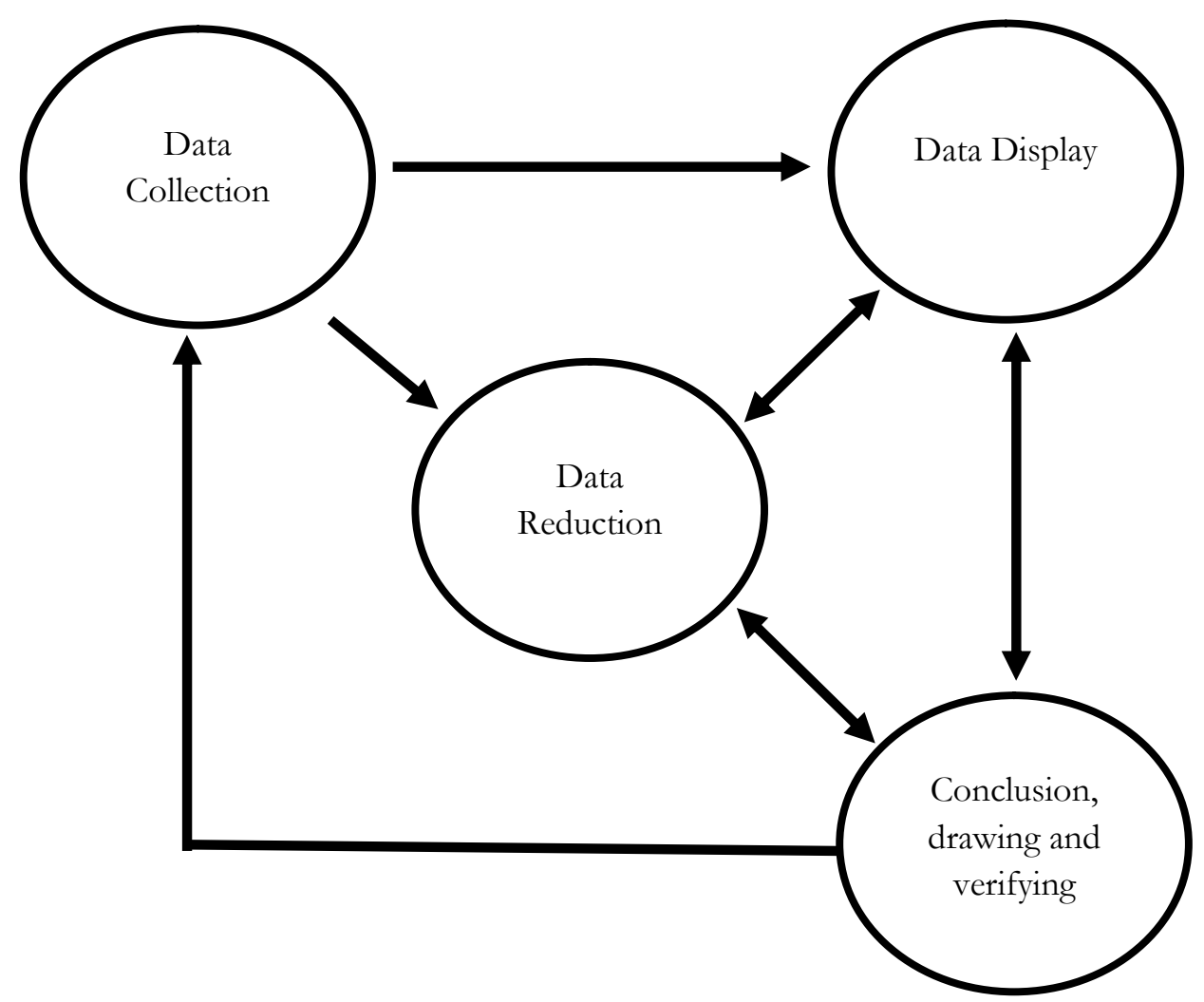

(adopted from Miles, B. Matthew, 1994)

The writer applied the following tables to investigate the status of Acehnese among Acehnese speakers in this research. 
Table IV

Attitudes category of Community Members towards Acehnese Language

\begin{tabular}{|l|l|}
\hline \multirow{2}{*}{ Category } & \multicolumn{1}{c|}{ Attitudes towards Language } \\
\hline \multirow{4}{*}{ Positive } & $\begin{array}{l}\text { All members value their language and wish to see it } \\
\text { promoted. }\end{array}$ \\
\cline { 2 - 3 } & $\begin{array}{l}\text { Most members support language maintenance. } \\
\text { are indifferent or may even support language shift. }\end{array}$ \\
\cline { 2 - 3 } Negative & $\begin{array}{l}\text { Some members support language maintenance; some are } \\
\text { indifferent or may even support language shift. }\end{array}$ \\
\cline { 2 - 3 } & $\begin{array}{l}\text { Only a few members support language maintenance; many are } \\
\text { indifferent or support language shift. }\end{array}$ \\
\cline { 2 - 3 } & $\begin{array}{l}\text { No one cares if the language is given up; all prefer to use a } \\
\text { dominant language. }\end{array}$ \\
\hline
\end{tabular}

Table V

Factors contributes to Language Attitudes and its implication

\begin{tabular}{|l|l|l|}
\hline Category & \multicolumn{1}{|c|}{ Indicators } & Effect \\
\hline & - Language is considered as an important symbol. & \\
Positive & - Effort to use the language at home. & \\
& - Ensure the language is used in school setting & \\
& - Eovernment of the country legislate the use of & Language \\
\hline
\end{tabular}




\begin{tabular}{|l|l|l|}
\hline & language in education. & \\
\hline & - Language is not used at home & \\
& - Language is not used at school setting & \\
Negative & - Language is not used at the place of worship. & Language \\
& - Community sees an important reason for & shift \\
& learning the second language. & \\
\hline
\end{tabular}

\section{FINDING AND DISCUSSION}

\section{Data display}

Attitude towards a language refers to the communitis' perception and tendency to react in a certain way either positif or negative towards that language. The positive and negative categories are classified based on the frequent use of the language.

From the questionnaire distributed to the respondents, it is seen that the respondents show positive and negative attitudes towards Acehnese vernacular maintenance. The attitudes show by the respondents was analyzed based on the theory as a temporary category of data analysis. The frequency of the attitudes of indigenous Acehnese people towards their vernacular maintenance occurred within the respondents at the age of 18 to 20 years old is shown in the table below:

\section{Table VI}

Positive and negative attitudes towards Acehnese vernacular

\begin{tabular}{|c|c|c|c|}
\hline \multicolumn{2}{|c|}{ POSITIVE } & \multicolumn{2}{c|}{ NEGATIVE } \\
\hline Respondent & Percentage & Respondent & Percentage \\
\hline
\end{tabular}




\begin{tabular}{|c|c|c|c|}
\hline $1,2,9,10,11,12$, & $55 \%$ & $3,4,5,6,7,8$, & $45 \%$ \\
$13,14,17,18,19$. & & $15,16,20$. & 4 \\
\hline
\end{tabular}

From the table displayed, it can be seen that the frequency of attitudes from respondents. Positive attitude which is shown by the respondent is higher than negative attitudes. This is due to the reason that $55 \%$ of respondents use Acehnese vernacular in all domain as medium of communication in their daily communication and $45 \%$ of respondents do not use Acehnese vernacular as the device of communication. Therefore, $55 \%$ of respondents considered to have positive attitude towards Acehnese vernacular maintenance, while 9 respondents (45\%) show negative attitude.

Positive attitude is an effort to use language in variety of domain, such as at home, school, and place of worship; this in line with what it is said by Holmes (2001) positive attitude supports efforts to use the language in variety of domain. Therefore, once the respondents have an eagerness to keep using Acehnese vernacular in variety of domain they can be categorized into positive attitude. Data of attitudes comprise 20 respondents. Based on the table it can be seen that $55 \%$ of respondent have positive attitude because they keep using Acehnese vernacular in all domain. It can be seen in the following interview:

\section{Data $1($ P/R. 07/)}

Researcher : In daily interaction, what language do you speak?

Respondent : I use to speak. Acehnese vernacular as a medium of communication.

Furthermore in the (Unesco, 2003) document on language endangerment stated that when community members' attitudes towards their language are positive, the language can be seen as a key symbol of identity. 
So, when community considered that their language is their identity, community will show positive attitude and force themselves to use the language. Even though language serves as means of communication and it is used to communicate with others to represent and exchange their experience of by using the language(s) they know. When people attempt to achieve a communication purpose they have to choose which of the language forms to use. The language they use is the representation of their identity; it is as Holmes (2001: 63) states that language is considered as an identity for a certain ethnic. This reason in using Acehnese vernacular in Langsa is occurred during interview as shown in data 3 and 4:

\section{Data $3(\mathrm{P} / \mathrm{R} / 07)$}

Because we are Acehnese, therefore we have to speak. Acehnese.

\section{Data 4 (P/R/19)}

It is the same as Indonesia language, Indonesian language is identity for Indonesian people. Therefore Acehnese vernacular is identity for Acehnese people.

From both of the data it can be conclude that, the respondents show positive attitude towards Acehnese vernacular because they aware that Acehnese vernacular is their identity. Moreover, positive attitude the people have towards their language or vernacular is a role of their families. Since family is considered as the basic unit of communities; because it consists of core family and extended families. Parents are the first person who has a great role in introducing a language to their children. Therefore, their children can see, hear and practice a language such as how the language spoken by their parents, by doing this activity Acehnese parents lead their 
children to be familiar with Acehnese vernacular and the children will use it in their daily interaction.

\section{Discussion}

After analyzing the data, there are some points that are considered as the important ones to be discussed.

From the data there are $55 \%$ of respondent shows positive attitude towards Acehnese vernacular. As in previous discussion it is known that attitudes refer to cognitive, affective and conative. Where cognitive component refers to a person's belief towards a language, affective refers to his reaction emotionally according to his previous belief towards the language, while conative is associated with his behavioral actions towards his belief. According to Yorio (1986) perception and belief can influence subjects cognitively towards an object. For instance, if students' perception towards an object is high, therefore they will give their full focus and effort towards that object. From positive attitude the respondents have towards Acehnese vernacular it is shown to us that the respondents tend use or speak Acehnese vernacular in their daily interaction. It is similar to what Holmes (2001) states that positive attitudes support efforts to use the language in variety of domains, and this helps people resist the pressure from majority group to switch to their language. It means that $55 \%$ of respondents support Acehnese vernacular maintenance, as Rajent (2012) states that language maintenance is generally describes as denoting the continuing use of a language in the face of competition from regionally and socially more powerful language. Once the community has positive attitude towards Acehnese vernacular, it leads community to keep using the language in various domain. 
Based on the data analysis respondent of indigenous Acehnese people always use Acehnese vernacular as medium of communication at home with their family, the use of Acehnese vernacular at home is having significant role in maintaining Acehnese vernacular since the member of family or children can hear the language from their parents and the children can practice it. According to Holmes (2001) the effort of nuclear family in using their vernacular language could help the language maintain. When parents make their children familiar with Acehnese vernacular, or keep practicing Acehnese vernacular at home, the parents make their children at the age of 18 to 20 years old able to speak Acehnese vernacular with good competence on it and it will give chances to their children to use and maintain Acehnese vernacular.

Positive attitude is shown by the respondents is a sort of their respect to Acehnese vernacular as their identity; the respondents feel proud to be Acehnese, as another ethnic who proud to their ethnic, interview with respondents support this reason, and this perception helps Acehnese people maintain their vernacular. Holmes (2001: 61) states that ethno linguistics also related to the attitudes of the language user to their language. When their language is seen as an important symbol of ethnic identity, it is generally maintained longer.

However positive attitude shown by indigenous Acehnese people is limited to some domain only such as home and their Acehnese friends. In another words it can be said that the respondents also show negative attitudes towards Acehnese vernacular maintenance, in the data analysis it is found that $45 \%$ of respondents show negative attitudes especially when they communicate with others when they are at school, religion domain, and even when they communicate with their neighbor. The pressure to be easily 
interacting with their new neighbors or friends has made them using Indonesian language frequently. It is similar with what Holmes (2001: 52) said that there is a pressure from the wider society to speak the dominant language. The use of the dominant languages regards them as a sign of successful assimilation in the new environment. However, the respondents speak the dominant language that is Indonesian language because they were born in Langsa since Langsa is not only inhibited by Acehnese people but some other ethnics as well. They have acquired Indonesian language since they are infants. Moreover, they speak Indonesian language with their neighbors, friends and teachers at school. They use Indonesian language because in their surrounding the dominant language used is Indonesian language. In order to be easily in communication among them, so, they "get on" in the society with friends, neighbors by using Indonesian language because Indonesian language is used in the wider society such as in Langsa

Due to the negative attitude they have towards Acehnese vernacular maintenance, it meant that the respondents don't use the Acehnese vernacular in their daily interaction and their language or vernacular is replaced by another. From the data analysis it can be seen that $45 \%$ of the respondents has negative attitude towards Acehnese vernacular which meant the respondents replace their language or vernacular with other language.

Moreover Indonesian language is national language and official language which is used as a lingua franca among ethnics inhibit in Langsa in order to communicate and to understand each other. So, the pressure from Indonesian language to Acehnese vernacular seems to be unavoidable, as Sneddon (2003) states that the pressure of Indonesian to local languages is very great and leads to their endangerment. 
School domain is considered as the second place where the respondents spend most of their time after home to interact each other either with their Acehnese friend or with other ethnic, at school the respondents use or speak Indonesian language dominantly rather than Acehnese vernacular, it is based on the consideration that Indonesian language is more prestigious and more powerful rather than Acehnese vernacular, and using or speaking Indonesian language will lead them to be easy to get through the knowledge or to understand school material. The status of Indonesian language as national and official language leads Indonesian language to be used as medium of instruction at school. This condition force respondents need to understand Indonesian language if they want to get success at school, at least to make them understand about what is explained by their teacher. So, it is parallel to Iskandar (2008) research on the students' attitude on using Acehnese in family, community and school. Where there are $26 \%$ of the students in Banda Aceh disagree to use Acehnese vernacular because it will constrain their knowledge, difficult to reach the development.

As from the finding shows to us that $45 \%$ of respondent has negative attitudes towards Acehnese vernacular, it simply can be understood that the respondents shift their Acehnese vernacular to more prestigious and more powerful language. Where language shift refers to the process by which one language displaces another in linguistic repertoire of community (Holmes, 2001). Moreover, whenever a big and a powerful language appear in foreign territory, small, indigenous languages will die (Nawaz Sana, 2012). This language shift so far becomes the initial step of the course of language death. Language death occurs in unstable bilingual or multilingual speech communities as a result of language shift from regressive minority language to dominant majority language. 


\section{CONCLUSION AND SUGGESTION}

The study concerned on the attitudes of indigenous Acehnese people towards Acehnese vernacular maintenance in Langsa. The aim of the study is to describe the attitudes of indigenous Acehnese people towards their vernacular maintenance. After deliberately analyzing the data, the conclusions are stated as follows:

1. The respondents show positive and negative attitudes towards Acehnese vernacular maintenance. There are 55\% of respondent show positive attitude and $45 \%$ of respondents show negative attitude.

2. The realization of positive attitude they have is by having an eagerness to keep using Acehnese vernacular with their family at home and with their Acehnese friends as medium of communication in their daily communication in variety of domain.

3. The positive attitude shown by respondents is because of their parents' roles that teach or make them familiar with Acehnese vernacular. The respondents show positive attitude towards Acehnese vernacular maintenance due to their respect to their identity.

In relation to the conclusion, the followings are suggested.

1. It is suggested that the Acehnese parents should keep using Acehnese vernacular in their daily communication. The habitually in using Acehnese vernacular affects their language children acquisition. Certainly, the children will learn the language from their parents. Then, they acquire Acehnese vernacular and the children can practice it with their parents and with other Acehnese in their daily communication.

2. It is suggested that the local government and language center should apply a program of revising Acehnese vernacular shift to keep 
maintain Acehnese vernacular by publishing books about Acehnese vernacular and by encouraging the love of the youth on the use of Acehnese vernacular through performing a story telling competition, and writing competition on Acehnese vernacular and it is also suggested to other researchers to be more concerned on the research about Acehnese vernacular maintenance.

\section{REFERENCE}

Bagozzi, R. (1992). The self-regulation of attitudes, intentions, and behavior. Journal of Social Psychology, 55,178-204.

Baker, Colin. (1992). Attitudes and Language. Clevedon: Multilingual matters.

Biro Pusat Statistik (BPS) Kota Langsa. 2012. Langsa.

Bogdan, Robert C. and Biklen. Sari Knopp. (1992). Qualitative Research for Education : In Introduction to Theory and Methods. Needham Heights: Allyn and Bacon.

Boyet L. Batang. (2010). Language Learning Attitudes of Selected Public and Private Secondary English Teachers in the Philippines. Philipines: Isabela State University.

Djam'an, S. (2009). Metode Penelitian Kualitatif. Bandung: Alfabeta.

Fishman, J. A. (1991). Language spread and language policy for endangered languages. Washington: Georgetown University Press.

Fishman, Joshua A. (1996). Language Loyality in The United States: The Manitenance and Perpetuation of Non-English Mother Tongues by American Ethic and Religion Groups. London, Paris: The Hague Mounton.

Holmes, Janet. (2001). An Introduction to Sociolinguistics. London: Longman.

Iskandar. (2008). Sikap Siswa SMA terbadap penggunaan Bahasa Aceh dalam Keluarga. Banda Aceh: Serambi Indonesia. 
Loveday, Lambert. (1982). The Sociolinguistics of learning and using a non-native language. Oxford: Pergamon Press.

Matthew B Miles and A. Michael Huberman. (1994). An expanded source book, qualiltative data analysis. London: International Educational and Profesional Publisher.

Matthias Brenzinger. (2003).Contribution to the UNESCO encyclopedia of life support systems (EOLSS). Documenting Endangerd Languages and Language Maintenance. Japan. Research Institute for Languages and Cultures of Asia and Africa, Tokyo University of Foreign Studies.

Musgrave, Simon. (2009). Language Shift and Language Maintenance in Indonesia. International Journal of The Sociology of Language, 1-17.

Natasha Mack. (2005). Qualitative Research Methods. A Data Collector's Field Guide. USA: Family Health International.

Rajend, Mesthrie. Introducing Sociolinguistics. Retrieved 25, February 2012, from http://www. Sociolinguistics.

Seidman, Irving. 2006. Interviewing as qualitative research: a guide for researchers in education. New York: Teachers College University Press.

Sneddon, James. (2003). The Indonesian Language, Its History and Role in Modern Society. Australia: University of New South Wales Press.

Yusri, Ghazali. (2011). Attitude towards oral arabic Among Students in Different Learning Environments. The International Journal of Language Society and Culture, 33, 37-44. 